\title{
Perempuan dan Kepemimpinan di Organisasi Mahasiswa Universitas Negeri Padang
}

\author{
Nurhayati Putri, Fatmariza \\ Prodi Pendidikan Pancasila dan Kewarganegaraan \\ FIS Universitas Negeri Padang \\ E-mail: Nurhayatiputri901@gmail.com
}

\section{ABSTRAK}

Penelitian ini bertujuan untuk menganalisis perempuan dan kepemimpinan di organisasi mahasiswa Universitas Negeri Padang. Metodologi yang digunakan dalam penelitian ini adalah mix method model Sequential Ekplanatory Design yaitu menggabungkan metode penelitian kuantitatif dan kualitatif secara berurutan, dimana pada tahap pertama penelitian ini dilakukan dengan metode penelitian kuantitatif melalui Angket, kemudian didukung oleh metode kualitatif melalui Wawancara dan Studi Dokumentasi. Hasil Penelitian menunjukkan bahwa Representasi perempuan dalam kepemimpinan di Organisasi mahasiswa rendah. Hal ini dibuktikan dengan pemimpin perempuan hanya 5,88\% perempuan yang menjadi pemimpin di Ormawa sejak tahun 2015-2020. Penyebab rendahnya kepemimpinan perempuan di Oganisasi mahasiswa Universitas Negeri Padang adalah : Perempuan tidak memiliki pengetahuan yang cukup dalam menjadi pemimpin dengan persentase sebesar 65\%. Perempuan dianggap kurang paham dalam mengambil kebijakan yang mempengaruhi orang banyak dengan persentase sebesar 62\%. Perempuan tidak percaya diri untuk menjadi pemimpin dengan persentase sebesar 47\%. ketidakyakinan kepada perempuan untuk memenuhi tanggung jawab menjadi pemimpin dengan persentase sebesar 44\%. Budaya patriarki melekat dalam lingkungan organisasi dengan persentase sebesar 59\%. tidak mampu mendisiplinkan orang dewasa terkhusus lakilaki dengan persentase sebesar 54\%. Perempuan tidak memiliki relasi yang kuat dalam memperoleh suara untuk memimpin dengan persentase sebesar 50\%. Sehingga hal tersebut membuat perempuan sangat sulit untuk menjadi pemimpin.

Kata Kunci: kepemimpinan, perempuan, organisasi mahasiswa

\section{ABSTRACT}

This reseach aims to analyze women and leadership in Padang State University student organizations. The methodology used in this study is a mix method model of Sequential Explanatory Design, which combines quantitative and qualitative research methods sequentially, where in the first phase this research was conducted with quantitative research methods through Questionnaire, then supported by qualitative methods through Interviews and Studies Documentation. The results showed that the representation of women in leadership in student organizations was low, this was evidenced by the female leader of 
only 5.88\% of women who became leaders in Ormawa since 2015-2020. which is the cause of the low leadership of women in Padang State University Student Organizations is: Women do not have enough knowledge in becoming leaders with a percentage of 65 percent. Women are considered to lack understanding in taking policies that affect people with a percentage of 62. Women are not confident to be leaders with a percentage of 47 . lack of confidence in women to fulfill the responsibilities of being leaders with a percentage of 44. Patriarchal culture inherent in the organizational environment with a percentage of 59. not being able to discipline adults especially men with a percentage of 54. Women do not have a strong relationship in getting votes to lead with a percentage of 50. So that it makes it very difficult for women to become leaders.

Keywords: leadership, women, student organizations

(c) (7) (9) This work is licensed under the Creative Commons Attribution-ShareAlike 4.0 International License. Br

\section{PENDAHULUAN}

Kepemimpinan tidak bisa terlepas dari individu yang memilki peran sebagai pemimpin. Peran ini banyak menghubungkan antara kemampuan individu dengan aspek biologis yaitu jenis kelamin antara lakilaki dan perempuan (Yulianti,Reny dkk,2018). Hal ini, menimbulkan ketimpangan gender yang memposisikan perempuan pada kondisi yang tidak menguntungkan. Kedudukan pemimpin sering di nilai sebagai jabatan "hanya" terbuka untuk lakilaki. Kecenderungan pembagian kerja yang di dasarkan jenis kelamin mencerminkan posisi perempuan berada dibawah lakilaki. Jika ada perempuan yang ingin menjadi pemimpin, maka perempuan harus memiliki kemampuan yang istimewa dan lebih tinggi dari pada lakilaki (Yulianti,Reny dkk,2018:15).

Laki-laki dan perempuan
memiliki kesempatan untuk
merepresentasi diri dalam memimpin
organisasi. Hak keterwakilan ini

tertuang dalam amanat UU No 39 tahun 1999 tentang Hak Asasi Manusia Pasal 49 ayat 1 yang berbunyi : "Wanita berhak untuk memilih, dipilih, diangkat dalam pekerjaan, jabatan, dan profesi sesuai dengan persyaratan dan peraturan perundang-undangan" (UU no 39,1999).

Dalam hal kepemimpinan, tidak ada satupun regulasi yang mendeskreditkan perempuan dalam kepemimpinan (Fitriani, 2015). Namun, nyatanya saat ini kedudukan perempuan dalam kepemimpinan belum mencapai target dalam pemenuhan kesetaraan gender. Jika diperhatikan, pemimpin perempuan belum terlibat banyak dilingkungan pemerintahan Indonesia. Salah satu data dari (kompas.com, 2020) bahwa jajaran kementrian di Indonesia maju tahun 2019-2024 Menteri perempuan hanya 5 orang. Kemudian, dalam posisi legislator Indonesia pada periode 2019-2024 posisi perempuan juga masih belum memenuhi 30 persen 
dari target keterlibatan perempuan dalam kursi DPR. Persentase perempuan di DPR periode 2019-2024 yang hanya mencapai 20,5 persen atau sebanyak 117 perempuan walaupun sudah meningkat dari tahun 2014 yaitu 97 orang, namun pemenuhan 30 persen keterlibatan perempuan dalam parlemen belum tercapai. Begitupun Gubernur hanya diisi oleh 1 orang atau 0,1 persen gubernur perempuan yaitu Khofifah Indar parasanwa di provinsi jawa timur. Kemudian dari 93 kota yang ada di Indonesia hanya 6 persen dari jumlah walikota di Indonesia yang menduduki kursi walikota.

Tidak menutup kemungkinan di Lingkungan kampus. Organisasi mahasiswa kampus UNP, khususnya perempuan masih berada pada posisi anggota kepengurusan dari pada menjadi pemimpin organisasi. Seperti menjadi sekretaris, bendahara, kesekretariatan dan anggota divisi bahkan kepala divisi masih di dominasi oleh laki-laki. Tahun 20142019 berturut turut hanya 8 persen dari 74 Organisasi mahasiswa yang ketua umum/ pemimpin adalah perempuan. Mahasiswa adalah agent of change, social control, iron stock yang mempengaruhi perkembangan kehidupan selanjutnya (Fibrianto, Alan sigit. 2016).

Penelitian yang dilakukan oleh Febrianto (2016) tentang Kesetaraan Gender dalam lingkup organisasi Mahasiswa Universitas sebelas Maret surakarta tahun 2016. Dengan hasil penelitian menunjukan minimnya peran perempuan dalam kepemimpinan ormawa universitas sebelas maret yang ditandai dengan posisi kepemimpinan organisasi mahasiswa di dominasi oleh laki-laki sedangkan posisi perempuan berada di jajaran sekretaris dan bendahara umum hal ini membuktikan bahwa organisasi mahasiswa Universitas sebelas maret belum mengedepankan konsep kesetaraan dan keadialan gender serta pengharusutamaan gender dilingkungan Kampus. Dalam hal ini, mahasiswa harus bisa memberikan contoh kepada masyarakat mengenai kesetaraan gender disegala bidang salah satunya adalah bidang kepemimpinan. Namun, implementasi kesetaraan di lingkungan mahasiswa masih rendah. Hal ini dapat dilihat dari sedikitnya kedudukan kepemimpinan perempuan dalam organisasi kampus.

Perlu di pelajari lebih lanjut kenapa di organisasi mahasiswa kepemimpinan perempuan sangan rendah, apa yang menjadi faktor penghambat kepemimpinan perempuan di organisasi mahasiswa tersebut. Untuk itu, penelitian ini perlu menganalisis secara komprehensif perempuan dan kepemimpinan di Organisasi Mahasiswa Universitas Negeri Padang.

\section{METODE PENELITIAN}

$\begin{array}{cc}\text { Jenis } & \text { penelitian ini } \\ \text { menggunakan } & \text { Metode deskriptif }\end{array}$ kuantitatif. Tahap pertama penelitian ini dilakukan dengan metode penelitian kuantitatif menggunakan teknik pengumpulan data yaitu Angket dari populasi sebanyak 28.780 dengan pengambilan sampel menggunakan rumus slovin sehingga sampel penelitian berjumlah 350 mahasiswa. Kemudian didukung dengan wawancara dan studi dokumentasi mengenai perempuan dan kepemimpinan.( Creswell dalam Sugiyono (2017: 404)). Tujuan peneliti 
menggunakan jenis penelitian ini, untuk memperoleh gambaran secara objektif dan komprehensif mengenai perempuan dan kepemimpinan di Ormawa UNP.

Penelitian dilakukan di 53 Organisasi Mahasiswa (15 Ormawa UNP, 5 BEM Fakultas, 5 BPM fakultas, 6 HMJ Fmipa, 6 HMJ Fis, 8 HMJ Fip, 4 HMJ Fbs, 4 HMJ Fe, BEM UNP, dan MPM UNP). Penentuan sampel lokasi didasarkan atas pertimbangan bahwa 53 organisasi ini populasi mahasiswa bersifat heterogen. Sedangkan Responden penelitian terdiri dari : (1) Ketua Umum Organisasi, (2) Sekretaris umum organisasi, (3) Pengurus Organisai. Teknik analisis data dalam penelitian ini menggunakan metode analisis deskriptif kuantitatif. Metode Kuantitatif dengan cara mengumpulkan data, menyusun data, dan menganalisis data sehingga dapat diketahui gambaran perempuan dan kepemimpinan di ormawa. Untuk memperkuat data, dilakukan wawancara dan studi dokumentasi.

\section{HASIL DAN PEMBAHASAN}

\section{Perempuan dan Kepemimpinan Di Universitas Negeri Padang}

Berdasarkan hasil penelitian, menunjukan bahwa perempuan di kepemimpinan organisasi mahasiswa masih rendah yaitu 6 persen. Bahkan dari 51 organisasi hanya 6 organisasi yang memberikan kesempatan kepada perempuan untuk menjadi pemimpin. Data tersebut memberi gambaran ternyata ada ketimpangan keterwakilan perempuan dalam kepemimpinan. Budaya patriarki masih melekat erat dalam kehidupan organisasi mahasiswa sehinga dominasi lakilaki masih terpatri dalam kepemimpinan organisasi. Secara lebih mendalam dapat dilihat di tabel 1

\begin{tabular}{|c|c|c|c|c|c|c|}
\hline \multirow[b]{2}{*}{ No } & \multirow{2}{*}{$\begin{array}{c}\text { Organisasi } \\
\text { (Berdasarkan } \\
\text { tingkat) }\end{array}$} & \multirow[b]{2}{*}{ Jumlah } & \multicolumn{4}{|c|}{ Klasifikasi } \\
\hline & & & LL & $\%$ & PR & $\%$ \\
\hline 1. & Universitas & 65 & 59 & 23 & 6 & 2 \\
\hline 2. & Fakultas & 50 & 48 & 19 & 2 & 1 \\
\hline 3. & Jurusan & 140 & 133 & 52 & 7 & 3 \\
\hline 4. & Jumlah & 255 & 240 & 94 & 15 & 6 \\
\hline
\end{tabular}

Dapat dilihat dari tabel 1 betapa ketimpangan posisi kepemimpinan perempuan di organisasi Universitas Negeri Padang. Padahal KH Husein Muhammad (dalam Zakaria, 2013 : 82) menyatakan perempuan memiliki kemampuan memimpin seperti yang dilakukan oleh laki-laki. Perempuan tidak selalu dikaitkan dengan sikap emosional tetapi juga sudah mampu berpikir rasional secara baik dan ideal.

$$
\text { Sehingga Fatmariza (2005) }
$$

Dominasi laki-laki yang cenderung patriarkhis dan bias gender senantiasa akan mengabaikan isu-isu perempuan seperti kesehatan reproduksi, kekerasan seksual, kesehatan ibu dan anak, dll. Dari data diatas hal ini menarik untuk dikaji apa yang menjadi penyebab rendahnya kepemimpinan mahasiswa di organisasi Kampus UNP sendiri adalah perempuan. Seharusnya perempuan merasakan ketidakadilan dalam kepemimpinan ini, namun berdasarkan temuan peneliti perempuan sendiri yang tidak menginginkan suatu jabatan pemimpin.

Hasil wawancara yang dilakukan dengan pengurus organisasi mahasiswa UNP penulis menyimpulkan bahwa penyebab rendahnya kedudukan perempuan dalam kepemimpinan organisasi didasarkan atas dua hal : (1) keinginan dirinya sendiri (Internal) bahwa 
perempuan itu sendiri yang tidak ingin menjadi pemimpin, Lingkungan organisasinya (Eksternal) yaitu budaya organisasi yang tidak pernah di pimpin oleh perempuan.

\section{Faktor yang mempengaruhi rendahnya perempuan kepemimpinan}

\section{Faktor Internal}

\section{a). Pengetahuan}

Pengetahuan menjadi salah satu dasar yang penting dalam sebuah kepemimpinan, Seorang pemimpin harus memiliki pengetahuan yang cukup untuk bisa memimpin apalagi sebuah organisasi. Salah satu pernyataan yang peneliti lakukan ternyata peneliti menemukan jawaban diuar dugaan peneliti. Berikut tabel dibawah ini:

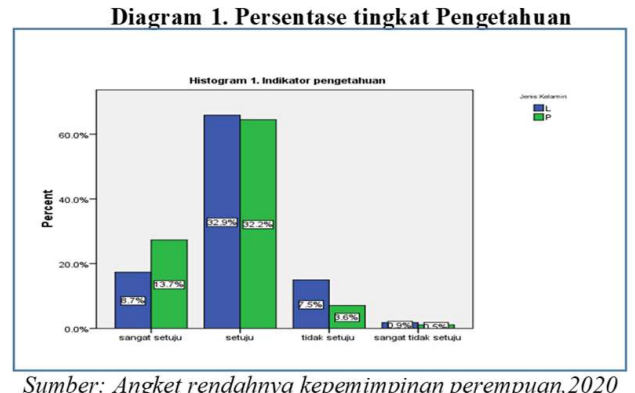

Diagram 1 menunjukan bahwa

65 persen responden setuju bahwa perempuan tidak memiliki pengetahuan yang cukup dalam menjadi pemimpin, ini berarti baik laki-laki maupun perempuan mengakui bahwa penyebab terhambatnya kepemimpinan perempuan di organisasi mahasiswa Universitas Negeri Padang adalah Pengetahuan. Sukses atau gagal yang dialami oleh organisasi sebagian besar ditentukan oleh kualitas kepemimpinan yang dimiliki oleh orang-orang yang diserahi tugasmemimpin dalam organisasi itu (Andjodah, 2015:7).

Data diatas menunjukan bahwa yang dari sebuah pemimpin adalah pengetahuan, dalam hal ini perempuan dianggap belum memiliki pengetahuan yang tinggi tentang kepemimpinan sehingga perempuan belum memiliki keberanian untuk menjadi pemimpin.

Hasil wawancara yang dilakukan dengan kepala departemen kaderisasi Himpunan Mahasiswa Jurusan PLB dan Kepala riset politik UK-WP2SOSPOL UNP penulis simpulkan bahwa perempuan hanya mengetahui kepemimpinan secara teori sedangkan dalam peimplementasian kepemimpinan perempuan cenderung lemah. Sebab perempuan lebih mengedepankan perasaan sedangkan lakilaki mengandalkan logika. Sehingga perempuan selalu dihadapkan dengan keputusan yang tidak berimbang dan masyarakat terdoktrin bahwa perempuan tidak memiliki pengetahuan yang cukup dalam memimpin. Kepemimpinan melekat kepada diri pemimpin dalam wujud kepribadian kemampuan (ability), dan kesanggupan (capability), dengan gaya dan kedudukannya dalam proses interaksi dan situasi yang ia rasakan. (Sudjana, 2010: 22).

b). Pemahaman

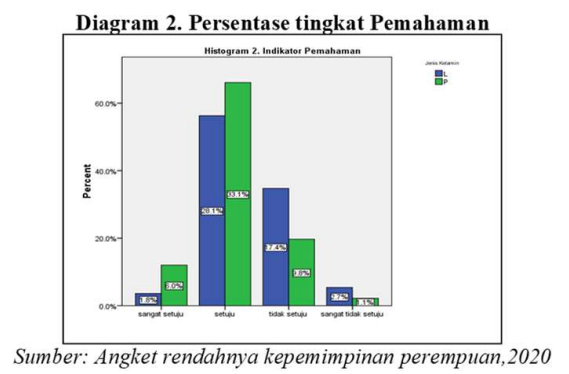




\begin{abstract}
Dari Paparan diagram 2 membuktikan bahwa Pemahaman juga menyebabkan terhambat kepemimpinan perempuan dalam kepemimpinan Ormawa di UNP dengan persentase sebesar 61 persen. bahkan 33 persen perempuan menyetujui bahwa perempuan dianggap kurang paham dalam mengambil kebijakan yang mempengaruhi orang banyak. Alasan yang kental disebutkan dalam wawancara adalah karna perempuan mengedepankan perasaan atau lebih emosional dalam mengambil kebijakan.
\end{abstract}

Sedangkan dalam kasus ini baik laki-laki maupun perempuan memiliki kesempatan yang sama untuk menjadi seorang pemimpin berdasarkan pertimbangan kapabilitas dan intelektualitas tersebut. Pandangan yang menyatakan bahwa perbedaan jenis kelamin menjadi halangan untuk memimpin tidak selaiknya dipertahankan karena kepemimpinan adalah demi kemaslahatan (zakaria, 2013 : 83).

c). Percaya diri

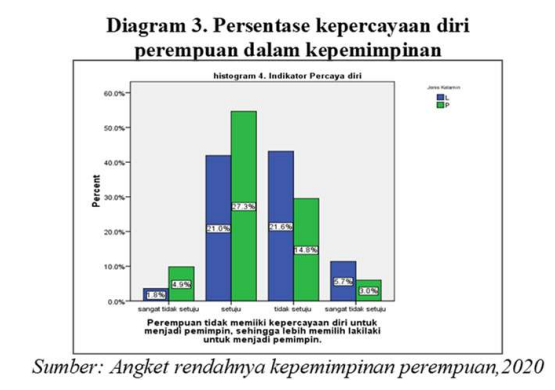

Dari pemaparan diagram 3 bahwa sebesar 48 persen responden mengakui bahwa rendahnya kepemimpinan perempuan di organisasi akibat ketidakpercayaan dirinya menjadi pemimpin. Bahkan 27 persen diantaranya adalah perempuan yang mengaku tidak percaya diri untuk menjadi pemimpin. Sehingga memilih lakilaki untuk menjadi pemimpin. Hal ini membuktikan bahwa memang perempuan sendiri yang tidak memiliki kepercayaan diri untuk menunjukkan diri menjadi pemimpin.

Membangun kepercayaan diri dalam memimpin menurut (Rini, Wahyu 2005 : 181) harus melatih empat dimensi kepribadian manusia: fisik, mental, emosi dan spiritual. Mereka selalu mempegnaruhi diri secara bertahap, sehingga dapat memerankan dirinya sebagai pemimpin yang memiliki visi yang benar dan memiliki mental yang baik. Inilah yang akan membuat karakter yang dimilikinya kuat dan sehat untuk memimpin. Sehingga pemimpin tersebut mampu membaca keadaan organisasinya agar bisa bergerak berdasarkan tujuan organisasi tersebut.

\section{d). Tanggung Jawab} Diagram 4. Persentase tingkat tanggung jawab perempuan dalam
kepemimpinan

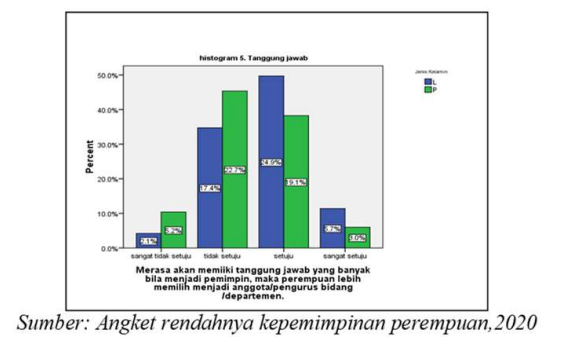

Dari paparan diagram 4 menunjukkan bahwa 44 persen responden menyetujui Perempuan tidak memiliki tanggung jawab yang cukup untuk menjadi pemimpin sehingga perempuan lebih memilih untuk menjadi anggota/pengurus bidang/ departemen. Karena Belum ada keberanian yang kuat oleh perempuan untuk menjadi pemimppin walaupun masyarakat tidak terlalu mempermasalahkan 
pemimpin laiki laki atau pun perempuan di organisasi Mahasiswa.

Perempuan dalam kehidupan memiliki beban tugas yang lebih berat daripada laki-laki. Walaupun perempuan memiliki hak yang sama dengan laki-laki bukan berarti perempuan meninggalkan tugas-tugas keperempuannya (Paksya, 2005 : 3). Sehingga tanggung jawab ini selalu mensandingkan perempuan dalam peran gandanya di kehidupan seharihari. Padahal menurut kartono (dalam Paksya, 2005: 7) baik perempuan maupun laki-laki memiliki tujuan yang smaa yang membedakan keduanya adalah fisiknya.

Berdasarkan hasil wawancara dengan perempuan pengurus organisasi mahahsiswa UNP menyatakan bahwa perempuan tidak memiliki kepercayaan diri untuk memimpin. Apalagi hal tersebut berkaitan dengan kegiatan yang besar dan organisasi yang besar. Perempuan lebih memilih aman dengan memilih tanggung jawab yang lain dan sesuai dengan kemampuan yang menurutnya sanggup untuk di emban seperti Sekretaris, Bendahara, dan kesekretariatan.

\section{Faktor Eksternal}

\section{a. Tradisi}

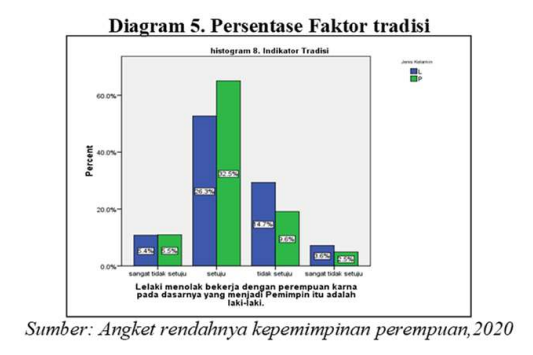

Dari paparan data, menunjukan faktor tradisi juga menjadi salah satu penghambat perempuan untuk menjadi pemimpin. Sebesar 59 persen responden menyetujui bahwa lelaki menolak bekerja dengan perempuan karena pada dasarnya yang menjadi pemimpin tersebut adalah laki-laki. Untuk lebih jelasnya perhatikan diagram 5. Bahkan dalam hal ini, 32,5 persen lelaki yang menyatakan hal tersebut itu artinya laki-laki menolak bekerja dengan perempuan jika perempuan tersebut adalah seorang pemimpin.

Hal tersebut dibenarkan oleh dewan pertimbangan Organisasi UKWP2SOSPOL menyebutkan "Jika ada pilihan lain selain dengan perempuan lebih baik pilih yang lain. Bekerja dengan perempuan termasuk sulit dalam menjalankan organisasi. Akan lebih baik perempuan tetap berada dibawah lakilaki, karna nyatanya perempuan adalah tulang rusuk dan perlu dibimbing". Hal senada juga dikatakan oleh mantan Sekretaris Umum PAW Badan Perwakilan Mahasiswa menyebutkan bahwa tak jarang perempuan tidak dihargai oleh lakilaki.

Dalam hal ini sering terjadi kekaburan dalam kehidupan seharihari antara ketimpangan peran kehidupan. Ada yang menganggap bahwa laki-laki lah yang cocok dalam mengemban tugas kekeluargaan dan menjalankan pemerintahan karena sudah menjadi tradisi dan kewajiban kehidupan (Zulfikri, 2010 : 5)

b. Kemampuan

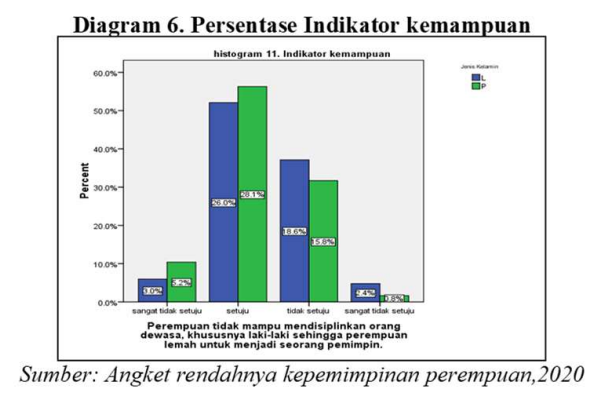


Diagram 6 menunjukaan sebanyak 54 persen responden menyatakan bahwa perempuan tidak mampu mendisiplinkan orang dewasa, khususnya lakilaki sehingga perempuan lemah untuk menjadi seorang pemimpin. Dari persentase diatas 28 persen perempuan sendiri merasakan bahwa mereka memiliki kesulitan untuk memimpin orang dewasa apalagi laki laki.

Berdasarkan wawancara bersama ketua umum Uk-Ganto simpulan peneliti adalah sulitnya mengatur jadwal dan korupsi waktu yang dilakukan anggotanya "Inilah kelemahan perempuan dalam memimpin. Menyamakan perasaan dan logika anggota yang lakilaki dan perempuan itu sedikit sulit". Hal itu senada dengan yang disampaikan oleh Ketua Umum UK-WP2SOSPOL menyebutkan bahwa perempuan tidak mampu mendisiplinkan lakilaki “Ketidaktegasan perempuan dalam memimpin membuat perempuan menjadi sulit untuk mendisiplinkan orang dewasa. Bahkan perempuan sendiri tidak disiplin seperti terlambat dalam rapat".

Biologis perempuan dianggap menjadi penyebab kerugian mereka pada semua tingkat masyarakat. Dimanapun umumnya perempuan kurang dikenal dan kurang publik. Karena secara kultur masyarakat dan agama perempuan berada diposisi subordinat terhadap laki-laki, dianggap masih berada dibawah pemimpin laki-laki. Sehingga dalam menjalankan keputusan baik ekonomi, politik, dan sosial serat diri perempuan itu sendiri perempuan tidak memilki hak suara apalagi mengambil dan menjalankan keputusan itu sendiri (Habibah, 2015: 103). c. Relasi

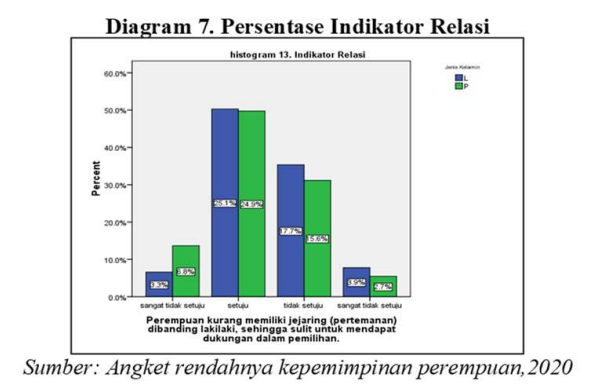

Relasi menjadi salah satu hal yang penting dalam memperoleh suara untuk menjadi pemimpin. Diagram 7 menunjukkan sebesar 50 persen responden menyatakan bahwa perempuan kurang memiliki jejaring pertemanan dibanding lakilaki, sehingga sulit untuk mendapatkan dukungan menjadi pemimpin. Akses perempuan terhadap ekonomi dan informasi sangat kecil. Ini mengakibatkan kesulitan bagi perempuan untuk meningkatkan posisi tawarnya dalam setiap rumusan kebijakan dan pengambilan keputusan menurut Tjokroaminoto (dalam Habibah, 2015: 103)

Hasil wawancara yang dilakukan dengan pengurus BEM Fakultas Ekonomi bahwa "Lakilaki punya banyak teman punya banyak relasi. Saat pemilihan kepemimpinan pasti banyak yang memilih lakilaki dengan salah satu alasan adalah dia suka berteman dan mudah dibawa kemana pun alur jalan organisasi. Sehingga perempuan jadi sulit menjadi pemimpin" Pernyataan yang sama disampaikan Sekretaris Umum Fakultas Matematika dan Ipa menyatakan kelemahan perempuan adalah kurang bergaul sehingga sulit mendapatkan suara "Jejaring pertemanan menjadi salah satu penyebab perempuan ini sulit menjadi pemimpin. Sebab perempuan perempuan punya batas dan bergaul 
Journal of Civic Education (ISSN: 2622-237X)

Volume 3 No. 32020

pun dibatasi. Sehingga memang berbeda luas pergaulan lakilaki dan perempuan".

Perempuan memiliki kekuatan yang lebih sedikit dibanding laki-laki. Ketidakseimbangan antara jenis kelamin adalah lebih besar dalam masyarakat dibanding faktor lain, dan perempuan bisa menjadi lebih dekat persamaan jika perempuan memiliki relasi yang banyak (Habibah, 2015: 103).

Dari data diatas dapat ditemukan beberapa hal: Pertama, Perempuan cenderung memiliki pengetahuan mengenai kepemimpinan berdasarkan teori. Namun, dalam peimplementasian perempuan masih cenderung lemah dan belum memiliki pengetahuan yang cukup. Karena untuk menjadi pemimpin tidak hanya mengandalkan perasaan namun logika pun juga harus imbang. Sehingga keputusan atau kebijakan yang dikeluarkan tidak merugikan organisasi dan anggota yang dipimpinnya. Kedua, Ketidakpercayaan diri perempuan menjadi perempuan selalu menduduki posisi yang strategis dalam organisasi posisi tersebut seperti sekretaris, bendahara, divisi kesekretariatan dan bidang bidang yang memudahkan pekerjaan perempuan dalam berorganisasi. Sehingga pekerjaan yang berisiko tinggi seperti pemimpin selalu dihindarkan. Ketiga, Tradisi Organisasi menuntut perempuan untuk tidak terlibat dalam kepemimpinan di organisasi Universitas negeri padang sebab budaya patriarki masih melekat kuat di lingkungan tersebut. Keempat, jejaring sosial menjadi salah satu alasan sulitnya perempuan untuk menjadi pemimpin. Hingga akhirnya pengalaman perempuan dalam mensejahterakan organisasi menjadi sedikit. Oleh karena itu, kebijakan yang dikeluarkan menjadi sulit dipertimbangkan.

\section{KESIMPULAN}

Kedudukan perempuan dalam Kepemimpinan Mahasiswa masih rendah yaitu 5,88 persen. Kondisi ini tidak menguntungkan bagi perempuan dalam upaya menciptakan kesetaraan Gender. Anggapan yang sangat kuat bahwa perempuan tidak memiliki kemampuan untuk menjadi seorang Pemimpin. Selain itu anggapan sosial kultural bahwa perempuan tidak mampu bekerja di ranah publik dan budaya patriarki menjala kendala tersendiri bagi perempuan untuk menjadi pemimpin.

Faktor yang menjadi penyebab rendahnya kepemimpinan perempuan di Oganisasi mahasiswa Universitas Negeri Padang adalah: (1) Perempuan tidak memiliki pengetahuan yang cukup dalam menjadi pemimpin dengan persentase sebesar 65 persen. (2) Perempuan dianggap kurang paham dalam mengambil kebijakan yang mempengaruhi orang banyak dengan persentase sebesar 62 persen. (3) Perempuan tidak percaya diri untuk menjadi pemimpin dengan persentase sebesar 47 persen. (4) ketidakyakinan kepada perempuan untuk memenuhi tanggung jawab menjadi pemimpin dengan persentase sebesar 44 persen. (5) Budaya patriarki melekat dalam lingkungan organisasi dengan persentase sebesar 59 persen. (6) tidak mampu mendisiplinkan orang dewasa terkhusus lakilaki dengan persentase sebesar 54 persen. (7) Perempuan tidak memiliki relasi 
yang kuat dalam memperoleh suara untuk memimpin dengan persentase sebesar 50 persen. Sehingga hal tersebut membuat perempuan sangat sulit untuk menjadi pemimpin.

\section{DAFTAR PUSTAKA}

Anjodah, Novechi. 2015. kepemimpinan perempuan dalam jabatab publik. Universitas Maritim Raja Ali Haji Tanjung Pindanng, Naskah Publikasi, Kepulauan riau.

Diakses 4 Mei 2020

Fibrianto, Alan sigit. 2016. Kesetaraan Gender dalam lingkup organisasi mahasiswa universitas sebelas maret. Junal analisa Sosiologi. Diakses 25 oktober 2019.

Fitriani, Anissa. 2015. Gaya Kepemimpinan Perempuan Jurnal TAPIs Vol.11 No.2 Juli-Desember 2015. diakses 7 november 2019.

Habibah, St. 2015. Kepemimpinan perempuan dalam perspektif gender. Sosioreligius vol 1 no 1 . Diakses 19 juli 2020

https://nasional.kompas.com/read/2 019/10/23/20271641/menteriperempuan-dalam-kabinetindonesia-maju-lebih-sedikitdibanding

Intruksi Presiden (Inpres) no 9 tahun 2009 tantang pengharusutamaan gender dalam pembangunan nasional.

Paksya, Gurniawan K. 2005. Peranan wanita dalam kepemimpinan dan Politik. Staf pengajar jurusan Pendidikan Geografi FPIPS UPI. Diakses 14 juli 2020

Rini, Wahyu Astjarjo. 2005. Membangun kepemimpinan Diri.
Moderenisasi vol 1 nomor 3 . diakses 18 juli 2020

Undang-Undang no 39 tahun 1999 tentang Hak Asasi Manusia

Wahjosumidjo. 2008. kepemimpinan kepala sekolah. jakarta : Rajawali perss. Yulianti, Reny dkk. 2018. Women leadership: Telaah kapasitas Perempuan sebagai Pemimpin. Jurnal politik dan sosial kemasyarakatan vol 10 no 2 (2018). diakses 28 oktober 2020.

Zakaria, Samsul. 2013. Kepemimpinan perempuan dalam perspektif hukum islam (Studi koperatif antara pemikiran KH Husein Muhammad dan Prof Siti Musdah Mulia). Khazanah vol 6 no 1 . Diakses 15 Juli 2020

Zulkfikri. 2010. Konsep Kepemimpinan Perempuan (Studi koperasi atas pemikiran Nassarudin Umar dan KH. Husein Muhammad). Skripsi : Universitas sunan kalijaga Yogjakarta. Diakses 18 Juli 2020 